\title{
INTERNATIONAL REAL ESTATE REVIEW
}

\author{
2013 Vol. 16 No. 1 : pp. $28-47$
}

\section{REIT Share Price and NAV Deviations: Noise or Sentiment?}

\author{
Nai Jia Lee \\ Department of Real Estate, National University of Singapore. Email: \\ rstlnj@nus.edu.sg
}

\section{Tien Foo Sing}

Corresponding author. Department of Real Estate, National University of Singapore, 4 Architecture Drive, Singapore 117566. Email: rststf@nus.edu.sg

\section{Dinh Hoang Tran \\ Department of Real Estate, National University of Singapore}

This paper empirically tests the sentiment and "noise" effects in Singapore REITs (S-REIT) over the periods from January 2005 to December 2010.Our empirical results show that trading volume is significantly and negatively correlated with price to net asset value (P/NAV) premiums in the contemporary term. However, lagged trading volume is found to have positive effects on P/NAV premiums, which imply that herd activities of uninformed investors in the last period drive up REIT stock prices. The finding supports the sentiment hypothesis, but rejects the fundamental argument on P/NAV deviations. We find that the sentiment effects are asymmetric. The sentiment effects are not observed in the "hot" markets during the pre-subprime crisis periods. However, the negative relations between trading volume and P/NAV premiums disappear in the post-crisis periods in 2008.

\section{Keywords:}

Net Asset Value; Noise Trading; Sentiment; Imperfect Market; and REIT 


\section{Introduction}

Studies in the US have shown that REIT stocks are traded at significant discounts in some periods, whilst priced at significant premiums relative to net asset values (NAVs) in other periods. There are two strands of literature that explain price-to-NAV (P/NAV) deviations in the REIT markets. The market microstructure literature argues that $\mathrm{P} / \mathrm{NAV}$ deviation reflects the "imperfect" price discovery process between direct real estate and stock markets. The private real estate market is illiquid. Information inefficiency (noise) that causes P/NAV deviations is, therefore, created mainly by stock market activities. The behavioral studies, however, argue that uninformed investors (noise traders), who trade on sentiment, are responsible for driving REIT prices away from the NAVs.

High trading volume not underpinned by positive fundamentals is construed by the literature as an overly optimistic signal of "noise-traders" in the REIT market. Is the positive correlation between trading volume and P/NAV in Singapore's REIT (S-REIT) market during the post-subprime crisis periods from August 2007 to August 2008 (Figure 1) an indication of the presence of sentiment trading? This study aims to empirically test the significance of sentiment and/or "noise" effects on price wedges between the REIT and direct real estate markets.

\section{Figure 1 Price-to-Net Asset Value (P/NAV) and Trading Volume of Singapore REITs}

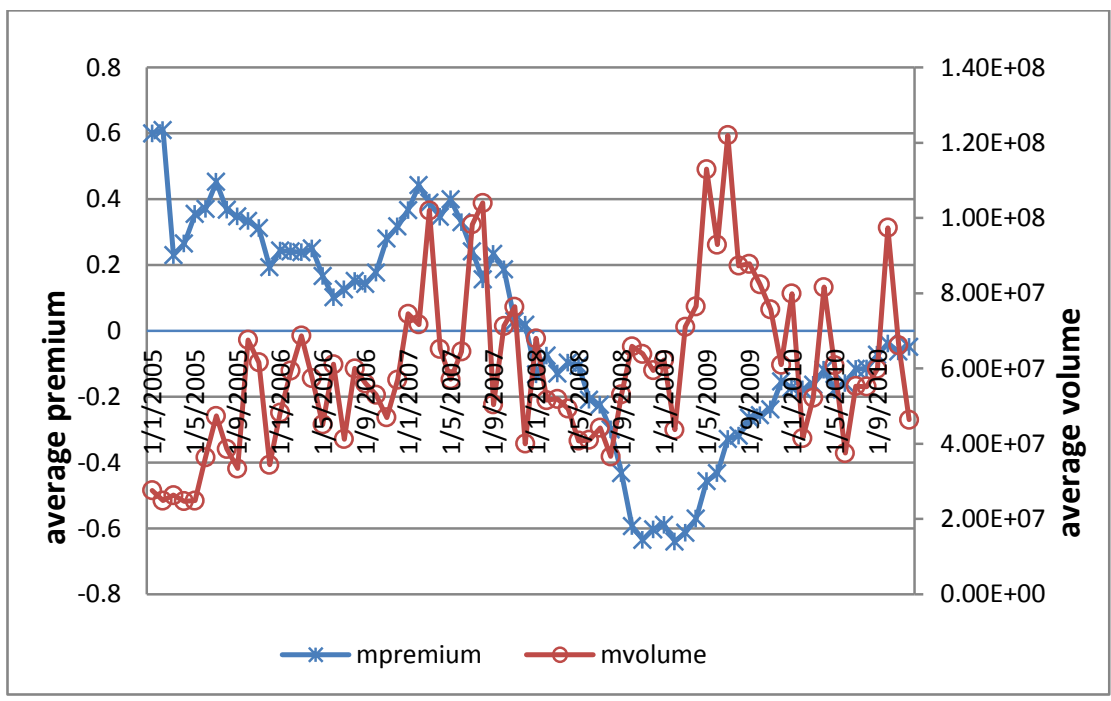


The S-REIT market is relatively small with a total capitalization of US\$ 28.23 billion (S\$37.10 billion) as of December 2010, which is approximately $7.86 \%$ of the US equity REIT market estimated at US\$358.91 billion. Institutional investors including S-REIT sponsors (insiders) hold more than $60 \%$ of the total shareholdings of average S-REITs. These two characteristics of the SREIT market create two opposing effects on P/NAV in the market. On the one hand, the small size of the S-REIT market imposes liquidity constraints that restrict an efficient price discovery process in the market. On the other hand, high institutional shareholdings reduce "noise" and sentiment trading in the market. The S-REIT market, therefore, offers a more restrictive environment in which stronger evidence is needed to support the presence of sentiment effects in the market.

Our empirical results show that there is a significant and negative contemporary correlation between $\mathrm{P} / \mathrm{NAV}$ premium and trading volume. The trading volume has lagged and significant positive effects on $\mathrm{P} / \mathrm{NAV}$ premiums. The S-REIT market is efficient, where investors do not over- or under-react to current shocks. However, our results support lagged herd behavior of uninformed investors that drives up REIT stock prices. This finding supports the sentiment hypothesis, but rejects the fundamental argument on P/NAV deviations. Our results show that the sentiment effects are asymmetric. The coefficients on the trading volume are negative when they are interacted with the pre-crisis period dummy. However, the negative correlation disappeared in the second half of 2008. The results imply that investors (arbitrageurs) become more risk-averse when experiencing large shocks during the subprime crisis.

This paper is organized into 5 sections. Section 1 outlines the importance of the research on price-to-NAV deviations for REITs, especially in the emerging Asian REIT markets that have been neglected. Section 2 reviews the relevant literature related to determinants of price-to-NAV premiums/discounts and also the noise and information theories that explain the price-to-NAV deviations. Section 3 describes the data used for the empirical tests. Section 4discusses the empirical model design and analyses of the results. Section 5 concludes the study with the limitations and a summary of the key findings.

\section{Literature Review}

There are extensive studies in the closed-end fund literature that examine the P/NAV puzzles. Retail investors in closed-end fund markets are easily influenced by fads in the market, and they herd and act on sentiment when making their investment decisions. Sentiment-based trading by these investors drives asset prices away from their fundamentals. Such sentiment-driven price risks, known as "noise trader risks", cause significant asset price anomalies in the closed-end fund markets (Delong, Shleifer, Summers and Waldman, 1990; Lee, Shleifer and Thaler, 1991; Gemmill and Thomas, 2002; Chordia and 
Swamina than, 1996). However, institutional investors, who are better informed, tend to move away from overvalued stocks (Lakonishok, Shleifer, Thaler and Vishny, 1992). Lee, Shleifer and Thaler (1991) attribute P/NAV deviations to the clientele effects of funds. While pessimistic investors push down the true values of underlying securities, overly positive investors price closed-end funds higher than underlying security values. When investors are optimistic, more new funds are formed in the market. The new fund flows can be used as a signal of sentiment change that predicts the discounts/premiums of P/NAV for closed-end funds (Gemmill and Thomas, 2002).

Like in closed-end funds, investor sentiment could also drive divergence in the P/NAV of REITs (Barkham and Ward, 1999; Clayton and McKinnon, 1999 and 2001). However, there are two differences in the microstructure between closed-end funds and REITs. First, real estate assets owned by REITs are less liquid compared to securities held by closed-end funds. The liquidity constraints in the private real estate market hinder the entry of sophisticated traders. Investors in the private market usually hold a long-term perspective for their investments, whereas the investor base in a more liquid public market is diversified, including both long and short-term investors, as well as dedicated and non-dedicated real estate investors (Clayton and McKinnon, 2001). Second, institutional investors are the major shareholders in REITs, especially in the emerging markets, whereas individual investors own the majority shares of closed-end funds. ${ }^{1}$ As institutional investors are less likely to herd on noise in the market, the impact of the sentiment of institutional owner son the mispricing of REITs is likely to be weaker (Gentry, Jones and Mayer, 2004). ${ }^{2}$ Informed investors could earn abnormal returns with a trading strategy that buys stocks traded at a discount to NAV and short stocks traded at a premium to NAV (Gentry, Jones and Mayer, 2004).

Clayton and MacKinnon (2001), by using trading volume as a proxy of investor sentiment, find that the positive effects of REIT market sentiment on premiums of REIT P/NAVs persist after accounting for liquidity risks. Clayton, Ling and Naranjo (2009) use a survey-based investor sentiment indicator published by the Chicago-based Real Estate Research Corporation (RERC), and a constructed market-based sentiment indicator to measure private commercial investor sentiment. They find significant evidence to support the causality of irrational investor sentiment on P/NAV discounts.

Unlike the sentiment hypothesis that is centered on investor irrationality, the information hypothesis argues for market imperfections as the factor behind the departure of share prices from NAV. Chordia and Swamina than (1996) explain that $\mathrm{P} / \mathrm{NAV}$ discounts on closed-end funds are endogenous in a

\footnotetext{
${ }^{1}$ The clientele effect could, however, still persist in REITs as long as individuals and institutions differ in their expectations (Grullon and Wang, 2000).

${ }^{2}$ Institutional investors could still behave like noise traders if they herd based on rational informational or irrational feedback (Nofsinger and Sias, 1999).
} 
rational setting with imperfectly informed small investors. Market imperfections, such as security market regulations, fiduciary responsibilities, and free-rider problems, make it difficult for rational investors to arbitrage away mispricing in closed-end funds. Barkham and Geltner (1995) and Gyourko and Kiem (1992) show that the public real estate market is a more efficient market compared tothe private real estate market. Price discovery occurs in the REIT market, such that REIT share prices lead direct real estate prices (Barkham and Geltner, 1995; Wang, Lizieri and Matysiak, 1997; and Glascock, Lu and So, 2000). Falls in REIT share prices forecast a downturn in the direct real estate market. Future NAVs are expected to decline in line with REIT share prices. As a result, discounts of P/NAVs will narrow without increases in REIT prices.

In studying the microstructure of the REIT market, firm-specific determinants are used to explain REIT P/NAV departures. In analyzing the cross-section P/NAV dispersions of REITs, Barkham and Ward (1999) and Clayton and MacKinnon (2001) find that market capitalization has a positive effect on REIT price premiums. They attribute the firm size effect to better access to capital markets, economies of scale and liquidity as REITs grow. Return volatility, both systematic and unsystematic (Clayton and MacKinnon, 2001; Bond and Shilling, 2004), potential capital gain taxes (Barkham and Ward, 1999; Gentry, Kemsley and Mayer, 2003) and leverage (Anderson, Conner and Liang, 2001) are found to have significant negative effects on REIT price premiums to NAVs.

The reputation and managerial skill of advisors will impact the valuation of closed-end funds (Malkiel, 1977; Chay and Trzcinka, 1999) and REITs (Ling and Ryngaert, 1997). A good REIT manager, who does not appropriate economic rents, generates positive premiums to REIT share prices relative to NAV (Gentry, Jones and Mayer, 2004).

\section{Data Analysis}

The S-REIT market was established in July 2002 via the listing of CapitaMall Trust (CMT), a retail mall REIT sponsored by CapitaLand, the largest listed real estate company in South East Asia. The initial public offerings (IPOs) of CMT were oversubscribed by five times. The number of S-REITs listed on the market has since rapidly expanded to 24 REITs, which have a total market capitalization of US\$21.1 billion as of October 2010. Based on the number of REIT listings and the total market capitalization, the S-REIT market is the second largest REIT market in Asia after Japan.

This study uses a sample of 23 listed S-REITs in the empirical analyses.3 Monthly data that represent financial ratios, stock market returns and trading

\footnotetext{
${ }^{3}$ There are currently 24 REITs listed on the Singapore Stock Exchange. The Sabana
} 
activities were mainly collected from Bloomberg which covered a six-year sample period from January 2005 to December 2010.Based on the monthly financial data, the following firm-specific variables were derived for our empirical tests. We defined two dummy variables for diversification strategies that have sector- and regional-focuses by using data from the real estate portfolio compositions of the sample REITs. The list of variables and their respective derivations are summarized in Table 1 .

The descriptive statistics in Table 2 show that the monthly P/NAV premiums range from -0.930 to 1.130 , and the average monthly P/NAV is estimated to be -0.114 , which indicates that the sample REITs are traded at a discount to NAV over the sample periods. Based on the historical book value of the aggregate asset, the average price to book ratio $(\mathrm{P} / \mathrm{BOOK})$ for the sample REITs is 0.888 . The highest $\mathrm{P} / \mathrm{BOOK}$ value is 2.49 . By market capitalization in Singapore dollar terms (S\$), the largest REIT is CapitaMall Trust, which was valued at S\$6.844 billion as of December 2010; whereas the smallest REIT is the Saizen REIT, which has a market capitalization of S\$45.20 million. The average market capitalization of the sample REITs is $\mathrm{S} \$ 1.361$ billion. S-REITs have a relatively low gearing ratio, which averages at $50.50 \%$ (or equivalent to a debt to asset ratio of $33.56 \%$ ). The most highly geared REIT borrows 1.58 times the equity, which is translated into a $61.30 \%$ debt to asset ratio. The institutional shareholdings in S-REITs are relatively high at $60.54 \%$ on average. In term of annual gross earnings, the average earnings before interest, taxes, depreciation, and amortization (EBITDA) was estimated at S\$37.107 million, and the Maple tree Industry Trust, which was listed in October 2010, recorded the highest EBITDA of S\$107.038 million. In terms of asset strategies, more REITs are focused by sector and geographical distribution of markets, where only $34 \%$ of the REITs hold mixed real estate assets in the portfolios, and $41 \%$ of them have cross-border exposure in their real estate portfolios. The descriptive statistics of other key variables are reported in Table 2.

\section{Empirical Methodology}

\subsection{Fixed or Random Effects}

To deal with the constraints of short time-series data, a panel data modeling technique is applied to the month-by-month unbalanced panel observations of 23 sample REITs over the periods from January 2005 to December 2010. The panel data account for both temporal variations and cross-sectional heterogeneity of the 23 REIT samples.

Shariah Compliant Industrial REIT listed in 2010 was not included in the sample because the financial data of this REIT are not available. 
Table 1 List of Empirical Variables and Their Derivations

\begin{tabular}{|c|c|c|}
\hline Name & Symbol & Description / Derivation \\
\hline \multicolumn{3}{|l|}{ Dependent Variables } \\
\hline Premium to NAV & $\mathrm{P} / \mathrm{NAV}$ & $\begin{array}{l}\text { The REIT-specific premium to NAV per share is defined as "(last price / NAV per share) - } 1 \text { ", } \\
\text { where the last price represents the closing trading price of REITs on the last trading day of the } \\
\text { month, and net asset value (NAV) per share is estimated as [common equity - intangible assets } \\
\text { common equity]. The asset values are based on the values reported in the financial statement } \\
\text { of firms. The intangible assets include outstanding share at par value, additional paid in } \\
\text { capital, and retained earnings. A negative premium, on a percentage term, is known as a } \\
\text { discount. }\end{array}$ \\
\hline Price to Book Ratio & $\mathrm{P} / \mathrm{BOOK}$ & $\begin{array}{l}\text { The ratio of stock price to book value per share is defined as "(last price/book value per } \\
\text { share)" }\end{array}$ \\
\hline \multicolumn{3}{|l|}{ Independent Variables } \\
\hline $\begin{array}{l}\text { Liquidity Premium } \\
\text {. }\end{array}$ & LIQDT & $\begin{array}{l}\text { The liquidity premium of REITs is represented by the relative effective spread measure. The } \\
\text { relative effective spread is a percentage measure of the transaction costs expected in a } \\
\text { transaction, which is computed as the effective spread divided by the mid price, where the } \\
\text { effective spread is defined as the absolute difference between ask price and bid price. }\end{array}$ \\
\hline Market Capitalization & MKTCAP & $\begin{array}{l}\text { The current market capitalization (in terms of million Singapore dollars) is a proxy of the } \\
\text { corporate size. It is the current monetary value of all outstanding shares stated in the pricing } \\
\text { currency, which is calculated as "(current shares outstanding * last price)". }\end{array}$ \\
\hline Debt to Equity Ratio & DEBTEQT & $\begin{array}{l}\text { The sum of short-term and long-term borrowings is divided by total shareholders' equity and } \\
\text { multiplied by } 100 \text { to obtain the total debt to total equity ratio. }\end{array}$ \\
\hline Monthly Volatility & VOLTY & $\begin{array}{l}\text { The price risk for a REIT is calculated from the standard deviation of day to day historical } \\
\text { price changes. The monthly volatility equals the annualized standard deviation of the relative } \\
\text { price change for the } 30 \text { most recent trading-day closing prices, expressed as a percentage. }\end{array}$ \\
\hline
\end{tabular}

(Continued...) 


\begin{tabular}{|c|c|c|}
\hline Name & Symbol & Description / Derivation \\
\hline \multicolumn{3}{|l|}{ Dependent Variables } \\
\hline $\begin{array}{l}\text { Institutional } \\
\text { Ownership }\end{array}$ & INSTOWN & $\begin{array}{l}\text { Institutional ownership is calculated as the sum of shareholdings of institutional owners, } \\
\text { such as investment advisors, hedge funds, mutual funds, insurance companies, etc., given } \\
\text { as a percentage of total ownership. }\end{array}$ \\
\hline Volume & VOLUME & $\begin{array}{l}\text { Total number of REIT shares traded in the current day. If the REIT has not traded, then it } \\
\text { is the total number of shares from the last day that the REIT traded. }\end{array}$ \\
\hline $\begin{array}{l}\text { Earnings before } \\
\text { interest, taxes, } \\
\text { depreciation and } \\
\text { amortization }\end{array}$ & EBITDA & $\begin{array}{l}\text { EBITDA (in S\$ million) is calculated as "(operating income + provision for loan losses }+ \\
\text { depreciation expense + interest expense)" }\end{array}$ \\
\hline \multicolumn{3}{|l|}{ Asset Dummies } \\
\hline$\overline{\text { Sector Diversified }}$ & DIVSECT & $\begin{array}{l}\text { A binary dummy variable, which has a value of } 1 \text { if REIT invests in properties in more } \\
\text { than one sector; } 0 \text { if REIT holds properties in only one sector. }\end{array}$ \\
\hline Region Focus & DIVREG & $\begin{array}{l}\text { A binary dummy variable, which has a value of } 1 \text { if REIT holds properties in more than } \\
\text { one country; } 0 \text { if REIT holds properties located in only one country. }\end{array}$ \\
\hline \multicolumn{3}{|r|}{. } \\
\hline Sub-prime periods & PRE & $\begin{array}{l}\text { A time dummy variable splits the time series into pre-crisis and post-crisis periods, and } \\
\text { the pre-crisis period has a value of } 1 \text { for the periods from January } 2005 \text { to December } \\
2007 ; 0 \text { indicates the post-crisis period that span from January } 2008 \text { to December } 2010 \text {. }\end{array}$ \\
\hline Crisis periods & CRISIS'”k" & $\begin{array}{l}\text { A time dummy variable that differentiates the subprime crisis effects; where } \mathbf{k}=(1,2) \text {, } \\
\text { that are "CRISIS } 1=1 \text {, if the samples are from January } 2008 \text { to June } 2008 \text {; and } \\
\text { "CRISIS } 2=1 \text {, if the samples are from July } 2008 \text { to October } 2008 \text {; and } 0 \text { otherwise. }\end{array}$ \\
\hline
\end{tabular}


Table 2 Descriptive statistics

\begin{tabular}{|c|c|c|c|c|c|c|}
\hline Variables & Symbol & Observation & Mean & Std. Dev. & Min & Max \\
\hline Premium to NAV & $\mathrm{P} / \mathrm{NAV}$ & 1039 & -0.114 & 0.410 & -0.930 & 1.130 \\
\hline Price to Book Ratio & $\mathrm{P} / \mathrm{BOOK}$ & 1039 & 0.888 & 0.403 & 0.090 & 2.490 \\
\hline $\begin{array}{l}\text { Market Capitalization } \\
\text { (S\$ million) }\end{array}$ & MKTCAP & 1033 & 1360.535 & 1303.372 & 45.200 & 6844.850 \\
\hline Debt to Equity Ratio & DEBTEQT & 1039 & 50.501 & 24.833 & 4.100 & 158.400 \\
\hline Monthly Volatility & VOLTY & 1039 & 35.571 & 21.510 & 8.180 & 274.550 \\
\hline Institutional Ownership & INSTOWN & 1039 & 60.538 & 25.140 & 3.310 & 99.540 \\
\hline Volume & VOLUME & 1039 & 64002057 & 71905230 & 539226 & 696330000 \\
\hline $\begin{array}{l}\text { Earnings before interest, } \\
\text { taxes, depreciation and } \\
\text { amortization (S\$ million) }\end{array}$ & EBITDA & 1039 & 31.530 & 22.673 & 0.657 & 107.038 \\
\hline Liquidity & LIQDT & 1039 & 0.013 & 0.012 & 0.000 & 0.170 \\
\hline Sector Diversified & DIVSECT & 1039 & 0.340 & 0.474 & 0.000 & 1.000 \\
\hline Region Focus & DIVREG & 1039 & 0.411 & 0.492 & 0.000 & 1.000 \\
\hline
\end{tabular}


Prior to estimating the panel regression models, Hausman tests are conducted to determine the significance of the fixed effects (FEs) and/or random effects (REs) of the panel data. In the Hausman test, if the null hypothesis is not rejected, the RE model is preferred, which allows for temporal variations in the intercept term; otherwise, the alternative FE model is used, where intercepts capture significant heterogeneity across the REIT samples. The Hausman test on the time invariant effects of individual REIT factors on P/NAV premiums shows a Wald statistic of 3.98, which does not reject the null hypothesis at the 5\% significance level, thus suggesting that an RE estimator is preferred. We tested the REs in the relationships between the $\mathrm{P} / \mathrm{NAV}$ premiums and the fundamental and liquidity variables. A Hausman test statistic of 2.95 is insignificant at both the $1 \%$ and $5 \%$ levels. Hence, the null hypothesis that the RE model is the preferred model is again not rejected.

\subsection{Empirical Results}

We ran the RE panel model with P/NAV premiums as the dependent variable against a vector of regressors that represent REIT fundamentals, which include market capitalization, debt to equity ratio, sector focus, region focus, monthly volatility, institutional ownership, trading volume, relative spread and EBITDA:

$$
y_{i t}=a_{i}+b_{i t}^{\prime} x_{i t}+\varepsilon_{i t}+v_{i}
$$

where $\varepsilon_{i t}$ is the REIT specific error term, and $v_{i}$ is the industry-wide heterogeneity across the REIT samples. The subscript $i$ denotes a sample REIT, and $t$ denotes the monthly sample observation.

\subsubsection{Base Model}

In Models 1, 2 and 3as shown in Table 3, we first ran panel regressions in contemporaneous terms with $\mathrm{P} / \mathrm{NAV}_{\mathrm{i}, \mathrm{t}}$ as the dependent variable. The results showed that the P/NAV premiums are positively and significantly correlated with the market capitalization of REITs (MKTCAP (M,t $_{\text {) }}$ and institutional shareholdings (INSTOWN ${ }_{i, t}$ ). The positive coefficient on MKTCAP $_{i, t}$ is consistent with the findings of Clayton and MacKinnon (2001), which imply that the REIT market places a premium on firm size effects. Larger REITs enjoy economies of scale and operational efficiency in their yield-accretive acquisitions and asset enhancement initiatives. The positive coefficient on institutional shareholdings signals interest alignment and transparency. REITs with shareholdings of large institutional investors, including block-holdings and insider shareholdings, attract wide coverage by analysts on the stocks. These more informed institutional investors, who take longer-term perspectives in their shareholdings, are unlikely to react to short-term "noise". Wang, Erickson and Chan (1995) have found that REITs with a higher percentage of institutional investors perform better than those with fewer or no institutional investors. 
Table 3 Panel Regression Results of Price-to-Net Asset Value (P/NAV)Ratios

\begin{tabular}{|c|c|c|c|c|c|c|c|c|}
\hline \multirow{3}{*}{$\begin{array}{l}\text { Variables } \\
\text { CONSTANT }_{i, t}\end{array}$} & \multicolumn{6}{|c|}{ Dependent $=\mathbf{P} / \mathbf{N A V} \mathbf{V}_{\mathrm{i}, \mathrm{t}}$} & \multirow{2}{*}{\multicolumn{2}{|c|}{$\begin{array}{c}\text { Dependent }=\text { P/Book } \\
\text { Model } 4\end{array}$}} \\
\hline & \multicolumn{2}{|c|}{ Model 1} & \multicolumn{2}{|c|}{ Model 2} & \multicolumn{2}{|c|}{ Model 3} & & \\
\hline & -0.190 & $*$ & -0.271 & $* *$ & -0.139 & & 0.867 & $* * *$ \\
\hline & $-(1.720)$ & & $-(2.350)$ & & $-(1.290)$ & & $(8.270)$ & \\
\hline MKTCAP $_{i, t}$ & $1.51 \mathrm{E}-04$ & $* * *$ & $1.60 \mathrm{E}-04$ & $* * *$ & $1.50 \mathrm{E}-04$ & $* * *$ & $1.50 \mathrm{E}-04$ & $* * *$ \\
\hline & $(10.080)$ & & $(10.650)$ & & $(10.130)$ & & $(10.260)$ & \\
\hline DEBTEQT $_{i, t}$ & $-3.60 \mathrm{E}-04$ & & $-4.20 \mathrm{E}-04$ & & $-4.59 \mathrm{E}-04$ & & $-4.63 \mathrm{E}-04$ & \\
\hline & $-(0.700)$ & & $-(0.820)$ & & $-(0.900)$ & & $-(0.920)$ & \\
\hline VOLTY $_{i, t}$ & -0.005 & $* * *$ & -0.005 & $* * *$ & -0.004 & $* * *$ & -0.004 & $* * *$ \\
\hline & $-(10.970)$ & & $-(10.700)$ & & $-(9.920)$ & & $-(9.880)$ & \\
\hline INSTOWN $_{\mathrm{i}, \mathrm{t}}$ & 0.004 & $* *$ & 0.005 & $* * *$ & 0.003 & $* *$ & 0.004 & $* *$ \\
\hline & $(2.250)$ & & $(2.920)$ & & $(2.140)$ & & $(2.400)$ & \\
\hline $\operatorname{VOLUME}_{\mathrm{i}, \mathrm{t}}$ & $-7.08 \mathrm{E}-10$ & $* * *$ & $9.77 \mathrm{E}-10$ & $* *$ & $-7.11 \mathrm{E}-10$ & $* * *$ & $-8.39 \mathrm{E}-10$ & $* * *$ \\
\hline & $-(4.530)$ & & $(2.430)$ & & $-(4.600)$ & & $-(5.470)$ & \\
\hline (INSTOWN* & & & $-2.49 \mathrm{E}-11$ & $* * *$ & & & & \\
\hline VOLUME) $_{\mathrm{I}, \mathrm{t}}$ & & & $-(4.540)$ & & & & & \\
\hline EBITDA $_{i, t}$ & $-1.77 \mathrm{E}-04$ & $* * *$ & $-1.70 \mathrm{E}-04$ & $* * *$ & $-1.42 \mathrm{E}-04$ & $* * *$ & $-2.07 \mathrm{E}-04$ & $* * *$ \\
\hline & $-(3.280)$ & & $-(3.220)$ & & $-(2.650)$ & & $-(3.920)$ & \\
\hline LIQDT $_{\mathrm{i}, \mathrm{t}}$ & & & & & -3.492 & $* * *$ & -3.891 & $* * *$ \\
\hline & & & & & $-(4.570)$ & & $-(5.130)$ & \\
\hline DIVSECT $_{i, t}$ & -0.234 & $* * *$ & -0.248 & $* * *$ & -0.225 & $* * *$ & -0.247 & $* * *$ \\
\hline & $-(2.940)$ & & $-(3.000)$ & & $-(2.910)$ & & $-(3.280)$ & \\
\hline DIVREG $_{i, t}$ & -0.023 & & -0.033 & & -0.022 & & -0.006 & \\
\hline & $-(0.300)$ & & $-(0.410)$ & & $-(0.300)$ & & $-(0.080)$ & \\
\hline R-square & 0.273 & & 0.286 & & 0.289 & & 0.309 & \\
\hline
\end{tabular}

Notes: $* * *$ denotes $1 \%$ significance level; $* *$ denotes $5 \%$ significance level and $*$ denotes $10 \%$ significance level. Absolute values of z-scores are shown in parentheses below each coefficient estimate. 
Volatility and volume are two variables that measure the market sentiment. If "noise" trading prevails in a volatile market, a large volume of trading activities usually follows due to the herd sentiment of uninformed investors. If high volatility and trading volume are sentiment driven, we should expect prices to be driven up by irrational (uninformed) investors. In our model, however, monthly market volatility $\left(\mathrm{VOLTY}_{\mathrm{i}, \mathrm{t}}\right)$ and trading volume $\left(V_{\text {OLUME }}, \mathrm{t}\right.$ ) are found to have significant, but negative impacts on P/NAV premiums of the sample REITs. The negative coefficients estimated on VOLTY $_{i, t}$ and VOLUME $E_{i, t}$ are inconsistent with the sentiment hypothesis. One possible cause for the negative relationships is related to arbitrage activities by informed investors, who possess and use superior information to pick underpriced stocks in a volatile market. Informed investors buy stocks at significant discounts; the arbitrageur activities drive up volatility and volume in the market, whilst causing prices to fall below the NAV. The negative relationships are further affirmed in Model 2, where an interactive variable, $(\text { INSTOWN*VOLUME) })_{i, t}$, which captures the joint effects of institutional shareholdings and trading volume, is added. A negative coefficient on the interactive variable shows that high trading volume in stocks with high institutional shareholdings is associated with low P/NAV stocks. The contemporary negative relationships between the sentiment proxies and $\mathrm{P} / \mathrm{NAV}$ do not support sentiment effects in the REIT market.

However, we observed that the inclusion of an interactive term changes the sign of the coefficient on VOLUME $_{i, t}$ from a negative to a positive value in Model 2. The VOLUME $E_{i, t}$ variable may capture the residual effects associated with trading activities by uninformed investors. Uninformed investors enter the market through herding in subsequent periods, and their trading activities cause prices to drift above the fundamental. The sentiment-driven trading activities by uninformed investors create lagged but positive effects on $\mathrm{P} / \mathrm{NAVs}$. The lagged volume and volatility are more likely to capture the sentiment of uninformed investors. The sentiment effects will be tested in the lagged models in the next section.

We controlled for gross earnings $\left(\right.$ EBIDTA $\left._{\mathrm{i}, \mathrm{t}}\right)$ in all three models and also liquidity premiums (LIQDT ${ }_{i, t}$ ) by using a relative spread variable in Model 3. The results showed that the two variables have negative and significant contemporaneous effects on P/NAV premiums. Subject to the $90 \%$ mandatory distribution requirement, high earning REIT stocks are synonymous to "value" stocks, and their prices are, therefore, expected to trade close to the NAV. In an illiquid market, high liquidity premiums depress prices which create a negative effect on P/NAVs.

In terms of the asset strategies of REITs, the results of the two asset dummies show that diversified REITs by sector $\left(\right.$ DIVSCT $\left._{i, t}\right)$ were traded at significant discounts to NAVs relative to focus-REITs. The regional diversification $\left(\right.$ DIVREG $_{i, t}$ ) effects on P/NAVs were, however, not significant. 
We followed up with a robustness check on the historical value effects by replacing the $\mathrm{P} / \mathrm{NAV}$ with price-to-book value $(\mathrm{P} / \mathrm{Book})$ as the dependent variable. The results are similar and consistent with previous studies. The historical book value in the P/Book variable does not change the findings, which may suggest that REITs constantly mark their assets to the market, and $\mathrm{P} / \mathrm{NAV}$ deviations are driven by noise and information imperfections in the market.

\subsubsection{Time-lag Effects}

In order to further test the lagged sentiment effects, we ran the panel P/NAV premium regressions against one-period lagged independent variables. In the Hausman tests, we found that the dependent variables and lagged independent variables are influenced by the same time invariant error terms. The FE model is rejected, and an RE estimator is thus used to estimate the lagged panel regression models in this section.

The lagged models that have an autoregressive term significantly improve the goodness-of-fit of the contemporary models, despite having a smaller number of significant coefficients. Table 4 shows that the R-squares of the lagged models range between 0.901 and 0.949 , compared with the highest of 0.289 in the contemporary model (Model 3). There are two key findings in the lagged models. First, we found a highly significant first order autocorrelation in the P/NAV. P/NAV shocks are highly persistent, which imply that the S-REIT market is inefficient. Informed investors could arbitrage on past price information. Second, in contrary to the results in the contemporary models, we found that coefficients on lagged trading volume, VOLUME $\mathrm{V}_{\mathrm{i}, \mathrm{t}-1}$, are significantly positively correlated with the current P/NAV premiums. The results are consistent with our inference that uninformed investors herd in the market and irrationally bid up REIT stock prices. The time-dependent sentiment effect in the S-REIT market is thus not rejected. We also carried out a diagnostic test of the reverse causality of $\mathrm{P} / \mathrm{NAV}$ premiums on volume. The results of Model 8 show significant positive relationships between $\mathrm{P} / \mathrm{NAV}_{\mathrm{i}, \mathrm{t}-1}$ and VOLUME $E_{i, t}$, which further support the sentiment-driven trading activities by uninformed investors, who irrationally chase up prices and drive up volume in the market.

The other two lagged independent variables, which are VOLTY $\mathrm{i}_{\mathrm{i}, \mathrm{t}-1}$ and DIVSECT $_{\mathrm{i}, \mathrm{t}-1}$, remain significant and the signs are negative.

\subsubsection{Hot versus Cold Market Effects}

We further explored the sentiment relationships that persist in a booming (hot) market and a depressed (cold) market. Figure 1 shows the average P/NAV dips into the negative region for the first time in January 2008 after the shocks of the sub-prime crisis. We used a dummy variable (PRE) to proxy the structural 
Table 4 Lagged Panel Regression Models of Price-to-Net Asset Values (P/NAVs)

\begin{tabular}{|c|c|c|c|c|c|c|c|c|}
\hline \multirow{3}{*}{$\begin{array}{l}\text { Variables } \\
\text { CONSTANT }\end{array}$} & \multicolumn{6}{|c|}{ Dependent $=\mathbf{P} / \mathbf{N A} \mathbf{V}_{\mathrm{i}, \mathrm{t}}$} & \multirow{2}{*}{\multicolumn{2}{|c|}{$\begin{array}{c}\text { Dependent }=\text { Volume }_{i, t} \\
\text { Model } 8\end{array}$}} \\
\hline & \multicolumn{2}{|c|}{ Model 5} & \multicolumn{2}{|c|}{ Model 6} & \multicolumn{2}{|l|}{ Model 7} & & \\
\hline & -0.008 & & -0.005 & & -0.007 & & \multicolumn{2}{|c|}{$-1.06 \mathrm{E}+07$} \\
\hline & $-(0.710)$ & & $-(0.470)$ & & $-(0.600)$ & & $-(0.980)$ & \\
\hline \multirow{2}{*}{ P/NAV ${ }_{\text {i.t-1 }}$} & 0.949 & $* * *$ & 0.948 & $* * *$ & 0.949 & $* * *$ & $-2.03 E+07$ & $* * *$ \\
\hline & $(93.000)$ & & $(91.580)$ & & $(91.840)$ & & $-(4.280)$ & \\
\hline \multirow{2}{*}{ MKTCAP $_{i, t-1}$} & $2.22 \mathrm{E}-06$ & & $2.03 \mathrm{E}-06$ & & $2.14 \mathrm{E}-06$ & & 9524.573 & $* * *$ \\
\hline & $(0.600)$ & & $(0.550)$ & & $(0.560)$ & & $(4.150)$ & \\
\hline \multirow[t]{2}{*}{ DEBTEQT $_{i, t-1}$} & $-1.58 \mathrm{E}-04$ & & $-1.58 \mathrm{E}-04$ & & $-1.60 \mathrm{E}-04$ & & $3.67 \mathrm{E}+05$ & $* * *$ \\
\hline & $-(1.150)$ & & $-(1.150)$ & & $-(1.110)$ & & $(4.950)$ & \\
\hline \multirow{2}{*}{ VOLTY $_{\text {i.t-1 }}$} & $-3.17 \mathrm{E}-04$ & $* *$ & $-2.98 \mathrm{E}-04$ & $*$ & $-3.20 \mathrm{E}-04$ & $* *$ & $1.20 \mathrm{E}+05$ & $*$ \\
\hline & $-(2.080)$ & & $-(1.940)$ & & $-(2.080)$ & & $(1.780)$ & \\
\hline \multirow[t]{2}{*}{$\operatorname{INSTOWN}_{\mathrm{i}, \mathrm{t}-1}$} & $1.89 \mathrm{E}-04$ & & $1.87 \mathrm{E}-04$ & & $1.82 \mathrm{E}-04$ & & $-1.05 \mathrm{E}+05$ & \\
\hline & $(1.310)$ & & $(1.300)$ & & $(1.070)$ & & $-(0.660)$ & \\
\hline \multirow[t]{2}{*}{$\operatorname{VOLUME}_{\mathrm{i}, \mathrm{t}-1}$} & $1.36 \mathrm{E}-10$ & $* * *$ & $1.35 \mathrm{E}-10$ & $* * *$ & $1.28 \mathrm{E}-10$ & & 0.377 & $* * *$ \\
\hline & $(2.630)$ & & $(2.610)$ & & $(1.080)$ & & $(6.270)$ & \\
\hline \multirow[t]{2}{*}{$(\text { INSTOWN*VOLUME) })_{\mathrm{I}, \mathrm{t}-1}$} & & & & & 0.000 & & 0.002 & $*$ \\
\hline & & & & & $(0.080)$ & & $(1.910)$ & \\
\hline \multirow[t]{2}{*}{ EBITDA $_{i, t-1}$} & $-8.56 \mathrm{E}-06$ & & $-6.88 \mathrm{E}-06$ & & $-8.55 \mathrm{E}-06$ & & 2179.782 & \\
\hline & $-(0.980)$ & & $-(0.770)$ & & $-(0.980)$ & & $(0.330)$ & \\
\hline \multirow{2}{*}{ LIQDT $_{i, t-1}$} & & $* * *$ & -0.223 & & & & & \\
\hline & & & $-(0.810)$ & & & & & \\
\hline \multirow[t]{2}{*}{ DIVSECT $_{i, t-1}$} & -0.015 & $*$ & -0.015 & $*$ & -0.015 & $*$ & $2.48 \mathrm{E}+07$ & $* * *$ \\
\hline & $-(1.930)$ & & $-(1.920)$ & & $-(1.900)$ & & $(3.260)$ & \\
\hline \multirow{2}{*}{ DIVREG $_{\mathrm{i}, \mathrm{t}-1}$} & 0.002 & & 0.002 & & 0.002 & & $-1.68 E+06$ & \\
\hline & $(0.250)$ & & $(0.260)$ & & $(0.250)$ & & $-(0.230)$ & \\
\hline R-square & 0.949 & & 0.949 & & 0.901 & & 0.4043 & \\
\hline
\end{tabular}

Notes: $* * *$ denotes $1 \%$ significance level; $* *$ denotes $5 \%$ significance level and $*$ denotes $10 \%$ significance level Absolute values of z-scores are shown in parentheses below each coefficient estimate. Model 8 is a robustness test on the reverse causality of P/NAVs on volume of trading. 
break that splits the sample periods into two, where $\mathrm{PRE}=1$, if the periods fall between January 2005 and December 2007, and PRE $=0$ for all other periods where $\mathrm{P} / \mathrm{NAV}$ is negative. The "PRE $=1$ " represents the hot market periods, where REIT stocks were traded at significant P/NAV premiums, whereas the post-subprime crisis periods were characterized by periods with REIT stocks traded at $\mathrm{P} / \mathrm{NAV}$ discounts.

We repeated the estimation $\mathrm{RE}$ panel regression models with a structural time dummy variable, and their interactions with other independent variables. The contemporary (Model 9) and lagged (Model 10) models are estimated and the results are summarized in Table 5. The results show that with the exception of the interactive debt-equity term, (PRE* DEBTEQT), and interactive regional diversification term, (PRE*DIVREG), all other interactive terms are significant at less than the 5\% level. The positive and significant coefficients on the time dummy variable, (PRE), show that P/NAV premiums are asymmetric in "hot" and "cold" markets.

We will further examine the asymmetric results in three parts. First, institutional shareholdings and volume variables are insignificant in both contemporary and lagged terms, but the interactive institutional shareholdings variable, $\left(\mathrm{PRE}^{*} \mathrm{INSTOWN}\right)_{\mathrm{i}, \mathrm{t}-\mathrm{k}}$, is significantly positive, and the interactive volume variable, $\left(\mathrm{PRE}^{*} \text { VOLUME) }\right)_{\mathrm{i}, \mathrm{t}-\mathrm{k}}$, is significantly negative. The results support the arbitrage argument, where institutional investors pick up underpriced stocks in large volumes which cause negative P/NAVs in the presubprime crisis periods. Interestingly, the sentiment effects are not observed in both contemporary and lagged interactive volume terms when the markets were on the uptrend.

The second group of variables involves those that have different signs between the control variable and their interactive variable. The volatility coefficient is negative in average market conditions, but the volatility in a "hot" market will drive positive P/NAVs. This may reflect the loss aversion of investors. Diversification by sector, DIVSECT $\mathrm{DI}_{\mathrm{i}, \mathrm{t}}$, is positively viewed in influencing P/NAV premiums in normal markets, but asset diversification is less favorable in a "hot" market when the P/NAVs of the diversified REITs are significantly discounted by investors. The third group of variables includes those that share the same signs in the control variables and their interactive terms. The coefficients on market capitalization and their interaction with a "hot" market are both significant and positive. The results imply that large REITs are priced at higher premiums in a hot market rather than a normal market. EBITDA $\mathrm{E}_{\mathrm{i}, \mathrm{t}-\mathrm{k}}$ and LIQDT $_{\mathrm{i}, \mathrm{t}-\mathrm{k}}$ have both negative coefficients in normal and interactive terms, which mean that high yield (gross earnings) and illiquidity constraints in the "hot" market retard the growth of REITs, which causes prices to significantly deviate below the NAVs. 


\begin{tabular}{|c|c|c|c|c|c|c|c|c|c|}
\hline \multirow[b]{3}{*}{ CONSTANT } & \multicolumn{3}{|c|}{$\begin{array}{l}\text { Contemporary model / } \\
\text { Interacted with "PRE" }\end{array}$} & \multicolumn{3}{|c|}{$\begin{array}{c}\text { Lagged Model / Interacted with } \\
\text { "PRE" }\end{array}$} & \multicolumn{3}{|c|}{$\begin{array}{c}\text { Lagged / Interacted with } \\
\text { "CRISIS2" }\end{array}$} \\
\hline & \multicolumn{3}{|c|}{$\begin{array}{c}\text { Model } 9 \\
(\mathbf{k}=\mathbf{0} ; \phi=\text { PRE })\end{array}$} & \multicolumn{3}{|c|}{$\begin{array}{c}\text { Model } 10 \\
(\mathrm{k}=1 ; \phi=\text { PRE })\end{array}$} & \multicolumn{3}{|c|}{$\begin{array}{c}\text { Model 11 } \\
(\mathrm{k}=1 ; \phi=\text { CRISIS2) }\end{array}$} \\
\hline & -0.220 & $-(2.880)$ & $* *$ & -0.217 & $-(3.130)$ & $* *$ & -0.152 & $-(1.740)$ & $*$ \\
\hline MKТСАР $_{\mathrm{i}, \mathrm{t}-\mathrm{k}}$ & $1.66 \mathrm{E}-04$ & $(14.550)$ & $* * *$ & $1.49 \mathrm{E}-04$ & (12.980) & $* * *$ & $1.31 \mathrm{E}-04$ & $(9.230)$ & $* * *$ \\
\hline DEBTEQT $_{i, t-k}$ & $-1.97 \mathrm{E}-05$ & $-(0.050)$ & & $2.42 \mathrm{E}-04$ & $(0.610)$ & & $-3.98 \mathrm{E}-04$ & $-(0.800)$ & \\
\hline VOLTY $_{i, t-k}$ & -0.003 & $-(10.850)$ & $* * *$ & -0.004 & $-(11.330)$ & $* * *$ & -0.003 & $-(7.110)$ & $* * *$ \\
\hline INSTOWN $_{\mathrm{i}, \mathrm{t}-\mathrm{k}}$ & $5.86 \mathrm{E}-04$ & $(0.520)$ & & 4.72E-04 & $(0.460)$ & & $3.66 \mathrm{E}-03$ & $(2.910)$ & $* *$ \\
\hline VOLUME $_{\mathrm{i}, \mathrm{t}-\mathrm{k}}$ & $-2.15 \mathrm{E}-11$ & $-(0.180)$ & & $1.82 \mathrm{E}-10$ & $(1.480)$ & & $-6.78 \mathrm{E}-10$ & $-(4.470)$ & $* * *$ \\
\hline EBITDA $_{i, t-k}$ & $-1.21 \mathrm{E}-04$ & $-(3.120)$ & $* *$ & $-1.13 \mathrm{E}-04$ & $-(2.970)$ & $* *$ & $-1.65 \mathrm{E}-04$ & $-(3.350)$ & $* * *$ \\
\hline LIQDT $_{i, t-k}$ & -1.397 & $-(2.570)$ & $* *$ & -1.331 & $-(2.360)$ & $* *$ & -3.304 & $-(4.270)$ & $* * *$ \\
\hline DIVSECT $_{\mathrm{i}, t-\mathrm{k}}$ & 4.083 & $(5.050)$ & $* * *$ & -0.273 & $-(5.420)$ & $* * *$ & -0.219 & $-(3.510)$ & $* * *$ \\
\hline DIVREG $_{\mathrm{i}, \mathrm{t}-\mathrm{k}}$ & -0.174 & $-(0.330)$ & & -0.021 & $-(0.440)$ & & -0.016 & $-(0.260)$ & \\
\hline$\phi * \mathbf{M K T C A P}_{\mathrm{i}, \mathrm{t}-\mathrm{k}}$ & $2.63 \mathrm{E}-05$ & $(2.020)$ & $* *$ & $1.42 \mathrm{E}-05$ & $(1.100)$ & & $-6.57 \mathrm{E}-05$ & $-(1.870)$ & $*$ \\
\hline$\phi^{*}$ DEBTEQT $_{\mathrm{i}, \mathrm{t}-\mathrm{k}}$ & $3.89 \mathrm{E}-04$ & $(0.630)$ & & $1.88 \mathrm{E}-04$ & $(0.340)$ & & $-5.50 \mathrm{E}-04$ & $-(0.500)$ & \\
\hline$\phi * \operatorname{VOLTY}_{\mathrm{i}, \mathrm{t}-\mathrm{k}}$ & 0.004 & $(3.160)$ & $* *$ & 0.006 & $(5.180)$ & $* * *$ & -0.002 & $-(1.710)$ & $*$ \\
\hline$\phi^{*} \operatorname{INSTOWN}_{\mathrm{i}, t-\mathrm{k}}$ & 0.001 & $(2.670)$ & $* *$ & 0.002 & $(2.980)$ & $* *$ & -0.001 & $-(0.550)$ & \\
\hline$\phi^{*} \operatorname{VOLUME}_{\mathrm{i}, \mathrm{t}-\mathrm{k}}$ & $-6.08 \mathrm{E}-10$ & $-(2.450)$ & $* *$ & $-7.60 \mathrm{E}-10$ & $-(2.960)$ & $* *$ & $4.66 \mathrm{E}-10$ & $(0.710)$ & \\
\hline$\phi^{*}$ EBITDA $_{\mathrm{i}, \mathrm{t}-\mathrm{k}}$ & $-1.10 \mathrm{E}-03$ & $-(5.320)$ & $* * *$ & $-7.92 \mathrm{E}-04$ & $-(3.770)$ & $* * *$ & $1.31 \mathrm{E}-04$ & $(1.950)$ & $*$ \\
\hline$\phi^{*} \mathbf{L I Q D T}_{\mathrm{i}, \mathrm{t}-\mathrm{k}}$ & -3.606 & $-(5.320)$ & $* * *$ & -4.125 & $-(2.740)$ & $* *$ & -0.373 & $-(0.872)$ & \\
\hline$\phi^{*}$ DIVSECT $_{\mathrm{i}, \mathrm{t}-\mathrm{k}}$ & -0.066 & $-(2.110)$ & $* *$ & -0.023 & $-(0.471)$ & & 0.085 & $(1.340)$ & \\
\hline$\phi^{*}$ DIVREG $_{\mathrm{i}, \mathrm{t}-\mathrm{k}}$ & 0.009 & $(0.290)$ & & 0.019 & $(0.600)$ & & -0.022 & $-(0.360)$ & \\
\hline PRE & 0.314 & $(5.270)$ & $* * *$ & 0.271 & $(5.560)$ & $* * *$ & & & \\
\hline CRISIS1 & & & & & & & -0.092 & $-(2.730)$ & $* *$ \\
\hline CRISIS2 & & & & & & & -0.146 & $-(1.620)$ & \\
\hline R-Square & 0.702 & & & 0.687 & & & 0.541 & & \\
\hline
\end{tabular}

Notes: $* * *$ denotes $1 \%$ significance level; $* *$ denotes $5 \%$ significance level and $*$ denotes $10 \%$ significance level Absolute values of $\mathrm{z}$-scores are shown in parentheses below each coefficient estimate. 


\subsubsection{Sub-prime Shocks}

As shown in Figure 1, we observed a positive correlation between P/NAV and trading volume in the post-subprime crisis. The declines in trading activities followed by downward adjustments in P/NAVs are signals of sentiment effects, and also the characteristics of investors who are becoming more riskaverse. Instead of splitting the market into regions by positive and negative $\mathrm{P} / \mathrm{NAVs}$ as in the earlier section, we more explicitly modeled the postsubprime effects on the P/NAV premiums of S-REITs by using two timedummy variables, known as CRISIS1 and CRISIS2. The first variable, CRISIS1 $=1$ if the observations are from January 2008 to June 2008; 0 otherwise, whereas CRISIS $=2$ is used to proxy the four-month periods from July 2008 to October 2008, and CRISIS $=0$ covers all other periods. October 2008 is the month when Singapore became the first Asian economy to fall into recession.

We repeated the panel regression estimation of Model 10, but replaced "PRE" with "CRISIS1" and "CRISIS2", and included interactive variables with a"CRISIS2" term. The results are summarized in Model 11 in Table 5. CRISIS1 is significant and negative which indicate that the REIT stocks are valued at a $9.2 \%$ discount to NAVs during the first six months in 2008. After controlling for the post-subprime crisis, we interestingly found that the volume coefficient becomes significantly negative, which may imply a significant loss aversion of investors during these periods. The panic disposal of stocks by investors in the post-subprime shocks caused prices to spiral downward, which widened the P/NAV discounts.

When the market experienced large systematic shocks, we found that the coefficient on market capitalization is significant and negative, but the coefficient on EBITDA is significantly positive. The results implied that investors are more pessimistic on large REITs, and instead prefer REITs with high gross earnings during periods of uncertainty. Investors are also more risk-averse in periods of crisis as reflected by a significantly negative coefficient on monthly volatility, (CRISIS2*VOLTY) $)_{\mathrm{i}, \mathrm{t}-1}$, which affirms that $\mathrm{P} / \mathrm{NAVs}$ were driven further apart in the aftermath of Lehman's collapse in 2008.

\section{Conclusion}

The debate on differential price discovery processes between public real estate (REIT) and private real estate markets has persisted in the literature for a long time. There are no conclusive evidence and consensus on the causality of the $\mathrm{P} / \mathrm{NAV}$ deviation in the real estate markets. If REIT and private real estate markets are integrated, we should expect investors to price REITs closely to the private values of underlying assets held in the portfolios. P/NAV 
deviations only exist in the two real estate markets, if there are differential risk premiums in the two markets. The behavioral literature argues that sentiment effects cause uninformed (noise) investors to irrationally trade in the REIT markets. This study empirically tests the information and "noise" effects on P/NAVs by using an unbalanced panel of monthly data of $23 \mathrm{~S}$ REITs over the periods from January 2005 to December 2010.

We have observed significant time-variation and asymmetry in P/NAVs in the S-REIT market over the sample periods. The P/NAV premiums are inversely correlated with the volume of REIT trading over most of the sample period. However, during the subprime crisis in late 2007 and 2008, P/NAV and trading volume move in tandem with each other. The negative sentiment as indicated by declines in trading volume causes REIT shares to trade at significant discounts to the NAVs.

We next run empirical tests on the effects of market fundamental and investor sentiment on P/NAV variations by using RE panel regression models. Our empirical results show that there is a significant and negative contemporary correlation between P/NAV premium and trading volume. The trading volume has significant lagged positive effects on P/NAV premiums. The S-REIT market is efficient, where investors do not over- or under-react to the current shocks. However, our results support the lagged herd behaviors of uninformed investors that irrationally drive up REIT stock prices. Our results show that the sentiment effects are asymmetric. The coefficients on the trading volume are negative when they are interacted with the pre-crisis period dummy. However, the negative correlation that reflects arbitrage activities in the market disappeared in the second half of 2008. The results imply that investors (arbitrageurs) become more risk-aversion rather than driven by sentiment when experiencing large shocks during a subprime crisis.

Unlike the earlier studies by Clayton and MacKinnon (1999, 2001) and Clayton, Ling and Naranjo (2009) who find significant sentiment induced P/NAV premiums in the US REIT market, we find weak evidence of sentiment effects of investors on P/NAVs in the S-REIT market. However, we expect noise traders to react to lagged information in the S-REIT markets, which explains why lagged volume is positively correlated with P/NAV. Our study that uses S-REIT samples may imply that curtailing costless and frictionless fund flows helps insulate a small and illiquid market against excessive volatility caused by investor sentiment. 


\section{References}

Anderson, R., Conner, P. and Liang, Y. (2001). Dimensions of REIT pricing: Size, growth and leverage. Prudential Real Estate Investors, Newark.

Barkham, R. and Geltner, D. (1995). Price Discovery in American and British Property Markets. Real Estate Economics, 23, 21-44.

Barkham, R. and Ward, C. (1999). Investor Sentiment and Noise Traders: Discount to Net Asset Value in Listed Property Companies in the U.K. Journal of Real Estate Research 18, 291-312.

Bond, S. and Shilling, J. D. (2004). An evaluation of property company discounts in Europe," European Public Association Research Paper.

Brounen, D., Ling, D. and Prado, M. P. (2010).Short Sales and Fundamental Value: Explaining the REIT Premium to NAV. SSRN Working Paper (http://ssrn.com/abstract=1469454).

Chay, J. B. and Trzcinka, C. A. (1999). Managerial Performance and the Cross-Sectional Pricing of Closed-End Funds. Journal of Financial Economics 52 (3), 379-408.

Chordia, T. and Swaminathan, B. (1996).Market segmentation, imperfect information, and closed-end fund discounts. Working Paper, Owen Graduate School of Management, Vanderbilt University.

Clayton, J., Ling, D. C. and Naranjo, A. (2009). Commercial Real Estate Valuation: Fundamentals Versus Investor Sentiment. Journal of Real Estate Finance and Economics 38, 5-37.

Clayton, J. and MacKinnon, G. (1999). The Dynamics of REIT Liquidity in a Down Market. Real Estate Finance 16:3, 36-43.

Clayton, J. and MacKinnon G. (2001). Explaining the Discount to NAV in REIT Pricing: Noise or Information? RERI Working Paper, January.

De Long, J. B., Shleifer, A., Summers, L. H. and Waldmann, R. J. (1990). Noise trader risk in financial markets. Journal of Political Economy 98(4), 703-738.

Glascock, J., Lu, C. and So, R. (2000). Further Evidence on the Integration of REIT, Bond, and Stock Returns. The Journal of Real Estate Finance and Economics 20, 177-194. 
Gemmill, G. and Thomas, D. C. (2002). Noise trading, costly arbitrage, and asset prices: Evidence from closed-end funds. Journal of Finance 57, 25712594.

Gentry, W. M., Kemsley, D. and Mayer, C. J. (2003). Dividend taxes and share prices: evidence from real estate investment trusts. Journal of Finance 58, 261-282.

Gentry, W. M., Jones, C. M. and Mayer, C. J. (2004). REIT reversion: Stock price adjustments to fundamental value. Working paper, Columbia University.

Grullon, G. and Wang, A. (2000). Closed-End Fund Discounts with Informed Ownership Differential. Working Paper, Jones Graduate School of Management, Rice University, Houston.

Gyourko, J. and Keim, D. (1992). What Does the Stock Market Tell Us About Real Estate Returns? Real Estate Economics 20, 457-485.

Lakonishok, J., Shleifer, A., Thaler, R. H. andVishny, R. W. (1992). The Impact of Institutional trading on Stock prices. Journal of Finance 46, 75-109

Lee, C., Shleifer, A. and Thaler, R. (1991). Investor Sentiment and the ClosedEnd Fund Puzzle. Journal of Finance 46, 75-109.

Ling, D. and Ryngaert, M. (1997). Valuation uncertainty, institutional involvement, and theunderpricing of IPOs: The case of REITs. Journal of Financial Economics 43, 433-456.

Liu, C.H., Hartzell, D. J., Greig, W. and Grissom, T. V. (1990). Integration of the Real Estate Market and the Stock Market: Some Preliminary Evidence. Journal of Real Estate Finance \& Economics 3: 261-282.

Malkiel, B. G. (1977). The valuation of closed-end investment-company shares. Journal of Finance 32, 847-859.

Nofsinger, J. R. and Sias, R. W. (1999). Herding and Feedback Trading by Institutional and Individual Investors. The Journal of Finance 54(6), 22632295.

Wang, K., Erickson, J., Gau, G. and Chan, S. H. (1995). Market Microstructure and Real Estate Returns. Real Estate Economics 23, 85-99.

Wang, P., Lizieri, C. and Matysiak, G. (1997). Information asymmetry, longrun relationships and price discovery in property investment markets. The European Journal of Finance 3, 261-275. 